\title{
ARTICLE
}

\section{Teaching Legal Ethics by Non-Ethical Means - With Special Attention to Facts, Roles and Respect Everywhere in the Legal Curriculum}

\author{
Special Issue on Education in (Professional) Legal Ethics, \\ Emanuel van Dongen \& Jet Tigchelaar (eds.)*
}

Hendrik Kaptein ${ }^{* *}$

\begin{abstract}
Legal ethics may be taught indirectly, given resistance to ethics as a separate and presumably merely subjective subject. This may be done by stressing the importance of facts (as the vast majority of legal issues relate to contested facts), of professional role consciousness and of the importance of formal and informal respect for all concerned. This indirect approach is best integrated into the whole of the legal curriculum, in moot practices and legal clinics offering perceptions of the administration of legal justice from receiving ends as well. Basic knowledge of forensic sciences, argumentation and rhetoric may do good here as well. Teachers of law are to set an example in their professional (and general) conduct.
\end{abstract}

Keywords: legal ethics, informal respect, educational integration, importance of setting examples.

\section{Introduction}

What may make teaching legal ethics an interesting subject? Or legal ethics itself for that matter? Such ethics for legal professionals is to set criteria for legal professionals' conduct, complementing explicitly legal regulation. 'Lawful but awful' is the core issue of legal ethics, stemming from the ethical imperfection of any legal order, however well developed and strictly adhered to.

Here it is suggested that legal ethics may be best taught 'indirectly': by paying attention to seemingly non-ethical and thus, hopefully, less contested issues like the importance of facts in the administration of legal justice, the importance of institutional facts and related role consciousness and the importance of respect in informal procedure. Such issues are best integrated into the whole of the legal cur-

* With many thanks to Law \& Method's reviewers, who provided most constructive feedback.

** Hendrik Kaptein is associate professor of jurisprudence em., Leiden University. 
riculum. These two main themes, 'ethics by non-ethical means' and 'integration', are here developed as follows:

Section 2 argues against belittling the subject: 'lawful but awful' may not really be something marginal in legal practice. A related problem is lawful procedure leading to materially unlawful results.

Section 3 discusses legal ethics supposedly setting standards here. Legal ethics may be taught in terms of applied ethics. But then there is widespread resistance against any ethics as more than 'merely subjective'. Discussion in terms of abstract values and norms may not be that practically fruitful anyway: 'Nobody ever became a better human being by studying Kant's categorical imperative.' ${ }^{1}$

Section 4 explains why legal ethics teaching may more appropriately begin with attention to facts determining application of law. There can be no doubt as to the immorality of legal decisions not based on the fact of the matter. More attention to facts may well do away with more than a few legal ethics concerns.

Section 5 stresses the importance of institutional facts determining professional roles for legal ethics. Explaining and exemplifying 'what a lawyer is good for' (or what any other legal professional is good for) may be more effective than abstract normative discourse as well.

Section 6 addresses (again hopefully uncontested) the importance of professional respect for all concerned as an essential part of professional roles. Well-mannered conduct in a broad sense is not merely a practical precondition for doing justice, but also for doing justice to all concerned itself. More attention to such 'informal justice' in teaching and in practice may forestall unnecessary conflicts as well.

Section 7 suggests integrating these 'stepping stones' towards legal ethics into legal curricula. This may be done in moot practices and in legal clinics, clarifying what it is 'to be in the position of parties at legal professionals' mercy'. Law courses inspiring this ought to pay due attention to legal principles too: 'no law without justice'. More attention to fact-finding and forensic sciences, rules of argumentation, rhetoric and respect for all concerned may do good here as well.

Section 8 notes that such integration does not imply exclusion of other ways of teaching legal ethics. However, any legal teaching may emphasize the human importance of administration of legal justice. In line with this, role awareness and professional competence are to be explained as giving personal meaning to professional lives as well. Legal (ethics) teachers are to 'set proper examples' themselves. ${ }^{2}$

1 A truism commonly attributed to Ágnes Heller.

2 A precautionary note: it will be clear from the outset that part of this contribution partly relies on empirical assumptions on (e.g.) the effectiveness of teaching legal ethics and on the occurrence and seriousness of (un)ethical attitudes and conduct in legal practice. The very nature of such factual issues precludes any conclusive establishment of evidence beforehand (but see also Section 7, with references to relevant literature). Still this article is partly informed by the author's international experience in teaching legal ethics to students and to legal professionals and by his experience as a legal advisor. Dangers of fallacious induction abound here, then, although, hopefully, more than a few readers may recognize the mild scepticism expounded here about legal ethics courses per se. 


\section{The Subject: Legal Professionals' Lawful Conduct with Awful or Even Unlawful Consequences}

Is there any legal ethics issue at all? Or is legal ethics' marginality best explained by the absence of any real immoralities in legal practice, maybe apart from a few classic 'really moral' issues like sex, abortion and euthanasia? Such a not uncommon and, in fact, commodious conception of legal ethics or what is left of it may be loosely based on the idea of law and legal practice being 'ruled' by so many detailed prescriptions that 'sticking to the law' apart from the odd irrational exception is enough in order to guarantee the legal and thus presumably also the human quality of the administration of the law. And then disciplinary law is appealed to as well, concerning not just violation of the rules but also conduct deemed unfit in a specific legal profession. ${ }^{3}$ Law is law, ethics is ethics? Legal practice ought not to be bothered by moralism? So what is left for legal ethics indeed?

This seemingly merely rhetorical question rests on a fundamental misunderstanding of the nature of law and its administration. It ought to go without much further saying that there is a distinction between law (including disciplinary law), on the one hand, and the well-nigh infinite range of more or less professional legal options within the limits of the law, on the other. Still such different options may have radically different consequences in terms of material justice and right, or at least in terms of the welfare of everybody (and every body) concerned.

Thus a lawyer may represent a client in court against another party who is clearly right. By some or other accident it becomes known to him that the lawyer representing the other party is going to miss a deadline unless somebody informs him of this. Remaining silent in this uncertain case may well lead to violation of the fatal time limit by the 'sleepy' lawyer and thus to simple victory for the client who is clearly wrong. Clear or not so clear as any case may be, remaining silent here implies frustration of the administration of justice without any violation of any specific legal rules, with possibly most serious consequences for losing (or simply duped) parties and others concerned. (One may lose in fair trial, but then there may still be the satisfaction of being duly heard and judged by a court instead of losing as a consequence of professional opportunism, incompetence or just laziness.)

'But a good lawyer is no Good Samaritan. In fact nobody is liable for other people's harm caused by their own faults.' Right, but then the problem is that missing the deadline (or whatever unprofessional conduct) is not the duped client's fault but the lawyer's. Or 'this depends on your professional conscience if you got any, it's everybody's own business' may be a standard reaction to issues like these. ${ }^{4}$

3 Disciplinary law refers to and thus depends on legal ethics, of course, in concepts like: 'conduct suitable for a lawyer'.

4 This historical case was discussed with several lawyers and other legal professionals. No consensus at all was apparent, not even on the nature of the problem. This is historically interesting as well: about 50 years ago any lawyer not fraternally forewarning a failing colleague in such a situation would be unconditionally ousted from the bar (in The Netherlands at least). Nowadays it is more or less the other way round: the messenger would receive a stern warning for 'not serving his client's interests' and the 'duped' client may sue his fraternally informative lawyer for damages. (What was the damage?). 
Or think of a case like the following. Someone tells a lawyer that after having had a couple of drinks he hit two cyclists while driving on the wrong side of the road while returning home at night. ${ }^{5}$ The victims were unconscious (dead?), just as there were no other witnesses in sight. What is the lawyer to do? According to the rules of client confidentiality, he may remain silent. He may even advise his client to remain silent on the accident as well. But such hiding of evidence may imply violation of victims' material rights and interests at least concerning damages. So here again is a 'lawful but unlawful' issue, with no clear legal answer and thus appealing to some or other professional legal ethics.

Evidence law itself may lead to procedural lawful but materially unlawful results. Party autonomy is traditionally thought to imply divisions of burden of proof, as, for instance, plaintiffs have to prove 'their own facts', defendants do not need to assist them in this to their own perceived disadvantage. Defendants ought to argue convincingly against plaintiffs' facts if they are to stand a chance in court. Still one party in procedure may be completely right but may not be able to prove his point, for material and/or procedural reasons. The other party's lawyers and/or others concerned may be fully aware of the real facts of the case but may still have motives to remain silent, with clear material injustice as the result.

Consequences of legal misconduct may not be directly unlawful but still be awful. Thus, public prosecution officers may start cases against 'easy targets' who may be disproportionally worse off as a consequence of such criminal prosecution without any general interest served. Richer and more powerful suspects or even offenders may be left alone. This is just one of many examples of not heeding proportionality and subsidiarity in the application of legal rules.

One more major issue of legal ethics is unequal distribution of legal services depending on income and social position. 'The price of justice': 'you may be right though you are poor', but still such right may not be realized against better-off opponents. Unequal distribution of legal services is but a small part of class justice or, in fact, class injustice in general, of course.

Lawful conduct in a wide sense may have many more awful consequences. Think here of lawyers advising clients to go to court with cases not surviving any real legal scrutiny but still good for lawyers' business. Or of a notary public advising on a last will without taking future family relationships into account. Or of judges more or less legally disregarding undeserved lack of evidence. Or of public servants ousting refugees according to 'the letter of the law'. Or of insurance companies employing legal staff specialized in warding off expensive claims however rightful... and so on.

The variety of such legal professionals' awful conduct is well-nigh endless, of course, however difficult, or even impossible, it is to quantify this problem in any meaningful sense. ${ }^{6}$ 


\section{3. (No) Ethics?}

Such 'lawful but awful or even unlawful' issues may indeed be belittled by denying any general standards of right and wrong transcending positive law. Then there can be no real awfulness and no real priority of material law and justice over procedural law (the 'unlawfulness' issue).

Indeed, it is widely assumed that there are no higher or even highest values and norms equally binding everybody. Or the law and other more or less accidental social norms and values are to be complied with, while all other conduct is subject to one's own conscience at best. Such a relativist or even subjectivist stance may reduce any legal ethics and thus any legal ethics course to meaninglessness in principle.

It may not make a lot of sense to try to refute such general relativism and subjectivism, at least not so in legal ethics courses. Yet any appeal to the authority of law must imply recognition of the basic values of law, such as protection of persons, property and promise, however differently detailed in different jurisdictions, in terms of fundamental rights and otherwise. So anybody respecting law also ought to respect relatively simple principles of retributive justice, such as the following: crime is to be punished, harm against persons and properties is to be compensated for and contracts ought to be enforceable. Distributive justice plays a major role in legislation in a wide sense as well, although such justice may be more political and thus ultimately more subjective than principles of retributive justice are.

Compared with such principles, positive law is much more detailed, of course. However, taking the law seriously implies respecting legal security in terms of positive material law in the first place as well. Such minimal 'legal norms and values' are presuppositions for the determination of what may be lawful but still awful or even unlawful.

Even if such a minimum of legal ethics is conceded it may be asked, 'why ought I to participate as well? Why not exploit a system sustained by others sticking to the rules to my own advantage?' Such an attitude of 'milking the system' may be countered by the question 'what makes your interests or even rights more valuable than anybody else's? Are you the centre of the world, or have you got a conscience?' 'Sure' may be the next move, but then 'my conscience is subjective: it is no more than my own responsibility, none of your business'.

Against this it may make sense to explain the original meaning of conscientia: 'knowing together'. It is, or at least ought to be, the knowledge that you are not alone in this world and that there is no reason why one person, be it you or anyone else, is endowed with a priori prerogatives:

[Conscience is] what makes one a really human being, with feelings related to others, however anonymous, and without any specific purpose or calculation, without thoughts of success and influence. (Canetti, 1976: 197) 
This relates to the Golden Rule:

Citizens cannot relate well to the complex world around them by factual knowledge and logic alone. The third ability of the citizen, closely related to the first two, is what we can call the narrative imagination. This means the ability to think what it might be like to be in the shoes of a person different from oneself, to be an intelligent reader of that person's story. (Nussbaum, 2010: 95)

Both conscience as 'knowing together' and the Golden Rule express the idea that 'you might as well have been that other person' and that it is, in fact, no more than just accident or even mere fortune that you are the legal professional and not the more or less passive subject having to bear with the possibly awful or even unlawful consequences of legal procedure. ${ }^{7}$

This all still has an air of the abstract. How effective may it be to explain law as not just technical complexity but a matter of principle as well? And how effective is it to teach the etymology of conscience? It may even be doubted whether any such explicitly ethical considerations may change the world for the better by any standards. $^{8}$

So it may not make a lot of sense to primarily teach abstract ethics and legal ethics as applied ethics to law students and to legal professionals or to people in general, for that matter. This, of course, is not to say that there is no interesting legal ethics literature. Luban, Wasserstrom, Rhode and many others paved the way for contemporary discussion of legal ethics. ${ }^{9}$ No legal ethics teacher can do without profound working knowledge of this. But then the issue here is, what is the added value for law students (in a broad sense) of such literature? ${ }^{10}$

\section{Facts}

Why not start with the facts? As explained before, any legal decisions not based on the facts of the case cannot be right, according to any standards of right and wrong. Even if such standards may be deemed to lack any general validity, the need to establish facts may still be a common ground. Da mihi facta dabo mihi ius? Adjudica-

7 'There but for the grace of God, goes John Bradford' (this - reputedly - did a 16th century court chaplain say to himself while seeing convicted on their way to the gallows: what more than mere fortune divides those who go free and those who are thwarted or even killed by the law).

8 See on senseless 'death marches through moral philosophy' and 'the functional equivalent of Cliff's Notes on Kant' Rhode, 2007: 1043-1057. See also Marks, 2013: ethics is best taught by not teaching it. Here the Golden Rule is not done away with in the end: see Section 6 on impersonal respect \& Section 7 on 'placing oneself in another's position'.

9 See, e.g., Wasserstrom, 1975, Wolfram, 1986, Luban, 1988, Rhode, 2000, and the recently updated handbook by Rhode, Luban, Cummings \& Engstrom, 2020, also on disciplinary law). (Anglo-American contributions to legal ethics more or less dominate discussions worldwide.)

10 See, for an extensive overview of legal ethics teaching worldwide, the website of The International Forum on Teaching Legal Ethics and Professionalism: teachinglegalethics.org. Most courses described are (not always compulsory) 'stand-alone' parts of legal curricula, often combined with disciplinary law teaching. Anyway the 'non-ethical and integrative' approach suggested here does not really figure prominently here. Predominant (again) are contributions from the English-speaking world. 
tion is about contested facts to a much greater extent than about contested law, just as legislation and other legal decisions presuppose clarity on the facts in the first place.

The importance of facts may seem self-evident; however, there may be doubts whether any facts may be more than 'relative' or even 'subjective'. For whatever (and sometimes outright opportunistic) reasons, facts may be reduced to 'what somebody makes of them'. No objective facts? Then no criticism of legal proof as 'contest' either, as this was based on possible conflicts with objective facts (see already Section 2). In such 'post-modernism' all factual dispute is just one more conflict or power struggle in order to 'solve' the original conflict.

If law is meant to regulate the world then it must take the facts of the matter into account, or there will be no effect for the better. So teach the importance of facts and thus of honesty about facts in the first place. And counter all too common ideas such as there being no need for special expertise in fact-finding in adjudication.

The facts of the case ought to constitute the common ground in any legal issue, or, in fact, in any issue of human importance. ${ }^{11}$ So legal professionals ought to honestly and accurately search for and to share such facts in the first place. ${ }^{12}$ This respect for facts is a first principle of legal and indeed of whatever professional ethics. Respect for facts is respect for human beings in touch with them - or just being them - for better or worse.

Sociology, psychology and economics of law may make good sense here as well, 'opening legal professionals' windows to the outside world'.

\section{Roles: The Morals of Institutional Facts}

Clarity on institutional facts determining professional roles is important in teaching legal ethics as well. The bar may furnish a good example here, contested as its role is given the competing interests of clients, commerce and law and society.

The classical explanation of the bar's essential role refers to the complexity of any rule and system of law as a presupposition of adequately handling the intricacies of modern social life. Since the beginning of law and of adjudication, laypeople needed help in the clarification and realization of their legal positions.

11 See against popular postmodernism, 'alternative facts', etc. Frankfurt, 2006: 100-101: '... our recognition and our understanding of our own identity arises out of, and depends integrally on, our appreciation of a reality that is definitively independent of ourselves. In other words, it arises out of and depends on our recognition that there are facts and truths over which we cannot hope to exercise direct or immediate control. If there were no such facts or truths, if the world invariably and unresistingly became whatever we might like or wish it to be, we would be unable to distinguish ourselves from what is other than ourselves and we would have no sense of what in particular we ourselves are. It is only through our recognition of a world of stubbornly independent reality, fact, and truth that we come both to recognize ourselves as beings distinct from others and to articulate the specific nature of our own identities.- How, then, can we fail to take the importance of factuality and of reality seriously? How can we fail to care about truth?-We cannot.'

12 Not discussed here are client confidentiality and other varieties of professional confidentiality possibly hiding facts important for the realization of justice and right. See Luban, 1988 for a or maybe the classic discussion of this. 
So far so good: with the due cooperation of legal professionals there may be more legal justice than without them, just as there will be more health thanks to medical professionals then in a world without them. However, there are so many ways in which lawyers may further awful or even unlawful clients' interests. Think here of cooperation in frustrating or even obstructing legal proceedings, putting unwelcome witnesses under undue pressure, doing away with unwanted evidence, cooking the books and so on. So 'clients' advantage', however often invoked as 'the' reason for being of the bar, cannot be the (whole) truth. It ought not to be the case that lawyers further clients' cases with less legal justice as the end result. ${ }^{13}$ Remember that a lawyer is an officer of the court as well.

Such reflection on roles determined by institutional facts again shows the importance of taking facts seriously in the first place. Such institutional facts are not just facts, of course, as they imply standards of professional conduct as well. For example, 'what a lawyer is implies what a lawyer is good for and thus what he ought to act up to'. This is an essential aspect of legal procedure as well and highly relevant for (teaching) legal ethics indeed.

This holds good not just for the bar, but for other role players in the administration of legal justice as well: what am I good for, as a lawyer, public prosecution officer, judge, public notary, sheriff, other public servant or even as a private legal adviser? You are not here for nothing.

\section{Respect: Informal Formalities or Professional Politeness and Impersonal- ity}

Such roles are most important parts of legal procedure. This is not just a legal issue. Being a legal professional implies behaving oneself in a generally 'unemotional', polite and attentive fashion respecting all concerned.

This is the 'impersonality' of the legal professional (or of any professional for that matter). The administration of legal justice is no 'family and friends' business. ${ }^{14}$ Legal professionals cannot do without factual knowledge, but they better do without too much personal knowledge of other participants in legal procedure.

Respecting legal rights in a wide sense implies respecting all concerned in the first place. Attentive politeness in all professional relationships will also facilitate legal proceedings by avoiding unnecessary conflicts. The basic rules of impersonal respect may in fact be more important in their legal and human consequences than so many legal formalities may be. The 'positive formality' of such rules, hopefully, ensures their uncontested acceptability, away from 'the subjectivity of ethics'. Here are some suggestions, in a more or less arbitrary order:

Always start with a lie, with the pia fraus ('pious fraud') of politeness or good manners. Even most threatening competitors, debtors, (other) offenders and so many more or less hated and terrible foes may be best approached with friendly

14 See Plessner, 1924 (and later editions) on the importance of impersonal society not determined by personal predilections. 
manners, according to the customs of the specific time, place and situation. Saying 'Good day' to some or other imagined or even real enemy may not be a bona fide expression of any real intention towards the addressee. Unexpected politeness and simple friendliness unrelated to any status, rank and (legal) importance may 'disarm' opponents and elicit reciprocal politeness and even goodwill.

Second, and in line with politeness, is the presumption of innocence (although there is no suggestion of any clear logical order here). Everybody is to be treated as being innocent, unless there is authoritative proof to the contrary. Nobody is to prove his innocence (apart from special circumstances even in criminal procedure).

Third, there is the overwhelming importance of audi et alteram partem ('Hear the other side'), not just in the establishment of any liability against anybody. This may not just lead to unexpected insights, acting on which may do justice to everybody concerned. Audi et alteram partem also or even primarily is an expression of respect for everyone concerned. Everybody concerned may have a say, thus being treated as an equal (see on this Hampshire, 2000).

Fourth, always try to be fully aware of all relevant facts (Section 4). This is not just a legal issue. Respect is impersonal in a sense, not necessitating intimate personal knowledge indeed. Still there may be non-legal factors highly relevant for legal outcomes. ${ }^{15}$

Fifth, and central, is the importance of discourse ad rem ('to the point'), as distinguished from discourse ad hominem ('against the person'). Discourse ought to be on the subject at hand, not on the persons involved in the discussion - unless these persons are the subjects of discussion themselves.

De nobis ipsis silemus ('on ourselves we are silent'). Just as it is respectful to 'remove yourself' from any disagreement or even conflict not having to do with yourself and/or your personal relationships. So do not 'translate' any conflict on any business (ad rem) into deterioration of any politeness (wrongly ad hominem). This not only respects other human beings involved but may also greatly facilitate the fruitful solution of any conflict.

Sixth, sometimes something needs to be done about or even against the fellow human beings concerned, according to whatever values and norms are at hand. Then, persons are to be respected according to the adage fortiter in re suaviter in modo: be forceful and effective in the business itself but act on this as carefully as possible.

Seventh, one or even the most important application of fortiter in re suaviter in modo concerns due apportionment of praise and blame. Praise fellow human beings for their good works, however near or far away they may be in social or whatever respects. Do not praise (or, for that matter, blame) human beings for their beauty or any other quality given to them, but praise them for their conduct (and duly express gratitude for anything supererogatory done for you: one more 'cement of society'). charity in the interpretation of whatever we try to express and convey. 
Ask yourself whether you are the one to blame somebody else and, if so, what your blame really adds up to in terms of a better future. 'Solve the problem, leave the people alone'. Do not ask for apologies, but do excuse yourself for any misconduct and try to undo its consequences.

Eighth and lastly - or better firstly - do not humiliate. So do not at all disclose any personal knowledge of other people's potentially shameful qualities and circumstances, unless there is overriding need to do so in order to prevent really harmful wrong.

Although these eight formal rules of conduct may not be too complex to memorize and even adhere to, they may still be loosely summarized in terms of the Golden Rule. The scope of 'treat others like you would like to be treated ...' is, of course, much wider. However, this part of the Golden Rule is a most important formality guiding professional conduct towards all concerned. ${ }^{16}$

Such impersonal respect for all concerned may well prevent unnecessary disciplinary and other formal procedures and their costs. It also serves self-interest, protecting the professional from adversary and other unwanted emotion and conflict. ${ }^{17}$

The importance of impersonal dignity and respect transcends legal professionalism, of course. But this is not to imply that its rules are irrelevant for legal ethics. Quite to the contrary. All legal ethics is applied ethics at least in the sense of explaining what it is to respect the dignity of all concerned as a basic human value in the administration of law and justice.

\section{Integrating Legal Ethics}

How to elicit legal ethics by training legal students (in a wide sense) in (at least) the hopefully uncontested importance of facts, professional role consciousness and due respect for all concerned? Integration of these factors into legal curricula (not excluding other legal ethics, of course) may ultimately be more ethically effective than separate courses perceived to be too far removed from the law as 'the proper subject'. This may be developed along the following lines:

a In moot courts and in other moot practices students ought to be trained in playing professional roles, in 'being' different participants in the administration of legal justice and in legal practice in general. Thus, students are to be trained and tested as court members, lawyers, public prosecution officers and in other legal roles. But students are also to act as clients, plaintiffs, defendants, victims of crime, subjects of proposed regulations limiting their civil liberties and rights and much more. Indeed, imagining oneself in the role of the

16 Compare this with Hobbes' obedience to 19 'immutable and eternal' natural laws as a basic presupposition for any viable society and (again) their summary in terms of the Golden Rule. See his Leviathan (1651 and later editions), chs. 14 and 15.

17 This is Hobbes' (dream of) egoism as universalism again. See more extensively, on respect and dignity, the present author's 'Human Dignity: What To Do With It? From Fruitless Abstraction to Meaningful Action' in Menuge \& Bussy, 2021. 
other may be more effective than any technical legal ethics literature. This is conscience and imagination (as abstractly explained in Section 3) in action.

b Legal clinics are to be the real-life sequel of this. Confrontation and some or other identification with real 'receiving ends' of legal proceedings may still better teach students what they are and will be doing as legal professionals to fellow human beings. ${ }^{18}$ Such pro bono practice may also elucidate the pressing problem of unequal distribution of legal services in society (see on legal clinics Luban \& Millemann, 1995: 31-88 and Nicholson, 2009-2010: 1-22, with extensive references).

c In such moot practices and legal clinics legal conduct possibly leading to awful or even unlawful consequences ought to be a central theme. This explicitly puts legal ethics back on the agenda, not as an abstract subject but in context. This is to teach students not only (so often soon forgotten) legal details but also responsible handling of legal prerogatives and legal options in general. Law and legal practice are to be explained as consisting not just of endless technicalities but of principles as well (as elucidated in Section 2 on 'the basic ethics within the law'), expressing purposes of law in order to further justice and right.

d A major part of any legal curriculum ought to be fact-finding and forensic science. Again, a host of legal issues are about facts. This again presupposes basic knowledge of statistics and probability, not just for issues of criminal evidence and proof. Different roles of different legal professionals in the establishment of evidence and proof are to be duly explained. This may be supplemented by empirical legal studies, further fostering awareness of 'the real world' and its relevance for legal ethics issues.

e In line with this, basic knowledge of logic and rules of argumentation ought to be part of the legal curriculum as well. Legal professionals may be fully aware of the law but may still act on the basis of fallacies like slippery slopes (e.g. against any qualification of client confidentiality), 'dependence on special circumstances', false appeal to equality, etc. Effective argumentation presupposes persuasion: basic training in rhetoric is another neglected part of many a legal curriculum.

$\mathrm{f}$ In line with rhetoric, there ought to be teaching on the informal rules of professional conduct, as discussed in Section 6. In fact, such teaching ought to be part of moot practices, legal clinics, etc. as well or may even be integrated into it. $^{19}$

Thus, the importance of legal ethics may be elicited by non-ethical means, in the whole of the curriculum (see also Rhode, 2007). This may make clear that although there may be no uniquely right answers to all legal ethics issues, some answers may be better than others.

This may be an even more effective way of teaching 'what it is like to be in the shoes of a person different from oneself' than just reading Nussbaum herself on this (as quoted in Section 3). And why not directly confront legal students with legal and not so legal realities, e.g. by acquainting them with prison life for a couple of months?

Mentoring may be useful here as well: see e.g. Ragavan, 2014: 401-424. 
In a wider sense the integration suggested here refers to the importance of integrating legal ethics into conceptions of good citizenship in general. A good legal professional also ought to be a good citizen (see again Nussbaum, 2010 and Maha$\mathrm{rg}$, 2007). Again, in the end, law is no end in itself.

Supplementary reading may be found, e.g. for example, in Plato's Gorgias on the conflict between Socrates and Callicles (in fact, the first and still standard-setting professional ethics dispute in the Western tradition), Epictetus' Diatribai, Camus' La Peste (or even L'Homme Révolté), and Von Schirach's recent Schuld. ${ }^{20}$ And in Tolstoy's The Death of Ivan Ilic, on the existential dissatisfaction and emptiness of a legal career without essential relationship to professional meaning and value.

This, of course, is a knowledge-attitude-practice approach. Socratic dialogue is an essential part of this, as is teachers' learning from students' attitudes and experiences. Character formation may be fostered by reference to role models of good practice. ${ }^{21}$ This may even lead to positive social control and positive peer pressure within specific legal professions like the bar. ${ }^{22}$ Whether the effectiveness of this 'non-ethical integration of legal ethics' is really greater than that of other ways of teaching legal ethics remains a complex, if not intractable, empirical issue. Nevertheless, it may be an important and fruitful subject for further research. ${ }^{23}$

\section{What Are You Looking For? It Is Here and Now}

What may this 'non-ethical' (and, of course, non-exclusive) proposal teach teachers of legal ethics? Of course, there ought to be no suggestion that explicit discussion of legal ethics is to be banned from any curriculum. There can be no legal ethics teaching without some or other explicit reference to more or less abstract legal ethics in the end. But, then, its relevance for legal practice ought to be clear from the outset.

So emphasize that there is no good law without good legal professionals. Duly explain that law is so much more than just a toolkit for exploitation of the rest of the world to one's own advantage: 'you make the law, don't break it'. ${ }^{24}$ And (again) stress the importance of facts and honesty on facts as a common ground, whatever

20 Other literature earlier referred to here may make sense in legal (ethics) curricula as well, like Frankfurt's On Truth: good for factfinding and Hampshire's Justice is Conflict: indispensable on audi et alteram partem. And of course: Luban \& Rhode, 2005 for some gripping casuistry.

21 See on the general issue of character formation extensively Aristotle, Ethica Nicomachea, and for a contemporary source Lapsley \& Power, 2005.

22 This relates to classic conceptions of the bar and comparable organizations as self-regulating, not just by disciplinary law but by informal means in the first place.

23 See precautionary note 3 on the relative intractability of such essentially empirical issues. Even large-scale state-of-the-art questionnaires on legal professionals' ethics attitudes and practices may not lead to results sufficiently reliable to be used as a basis for law school reform. Informed guesswork may be the best to have had here, although this need not stand in the way of sensible reform, of course. But see also, and on a less sceptical note, Nicholson, 2009-2010 for detailed discussion of effects of legal ethics teaching, including further references, $\mathrm{Wu}, 2017: 242-267$ and generally JDoris et al., 2013, Killen \& Smetana, 2014 and Vargas \& Doris, (in print).

24 Rhode, 2007: 1056: 'Lawyers have considerable power over the terms of their own practice and a range of ways to leave the world slightly better than they found it.' 
one's standpoints and positions. Compare the legal profession serving justice with the medical profession and its essential role for a healthy society. Emphasize the dependence of so many individuals and bodies on the quality of the legal profession and thus the importance of legal professionals. 'Law school is for life, not just for your life.'

So also, emphasize time and again the ethical or simply human importance of good legal workmanship as essential for professional roles. Highlight the satisfaction to be derived from living up to such professional roles instead of exploiting them to wrongly perceived personal advantage. And tell your students that they have enormous prerogatives compared with the many others who are less endowed, not just in the sense of expected income, social position and work satisfaction but also in being so much better armed against legal and other mischief.

'What are you looking for? It's here and now': teaching legal ethics starts with setting the example yourself. Stick to at least the basic precepts of respect as briefly expounded in Section 6 in all relationships with students as well. Serve in the university as the community (universitas) of teachers and students serving the world. Set the example:

[Denn] wenn sie als reine Vernunft wirklich praktisch ist, so beweiset sie ihre und ihrer Begriffe Realität durch die Tat, und alles Vernünfteln wider die Möglichkeit, es zu sein, ist vergeblich. (Kant, 1788)

\section{References}

Canetti, E. (1976). Das Gewissen der Worte. München: Hanser.

Doris, J. M. et al. (2013). The moral psychology handbook. Oxford: Oxford University Press.

Frankfurt, H. G. (2006). On truth (pp. 100-101). New York: Alfred A. Knopf.

Hampshire, S. (2000). Justice is conflict. Princeton, NJ: Princeton University Press.

Kant, I. (1788 and later editions). Kritik der praktischen Vernunft. Vorrede (Ágnes Heller rebuked in the end?).

Killen, M. \& Smetana, J. G. (2014). The handbook of moral development. London: Routledge / Psychology Press.

Lapsley, D. \& Power, C. (2005). Character psychology and character education. Notre Dame: University of Notre Dame Press.

Luban, D. (1988). Lawyers and justice: An ethical study. Princeton, NJ: Princeton University Press.

Luban, D. \& Millemann, M. (1995). Good judgment: ethics teaching in dark times. Georgetown Journal of Legal Ethics, 9(1), 31-88.

Luban, D. \& Rhode, D. L. (Eds.) (2005). Legal ethics: Law stories. St. Paul, MN: West Academic.

Maharg, P. (2007). Transforming legal education: Learning and teaching the law in the early twenty-first century. London: Ashgate.

Marks, J. (2013). Ethics without morals: In defense of amorality. New York \& London: Routledge.

Menuge, A. J. L. \& Bussy, B. W. (Eds.) (2021). The inherence of human dignity, Vol. 1: Foundations of human dignity. New York: Anthem Press. 
Nicholson, D. (2009-2010). Teaching legal ethics: What, how and why. Revista de Educación y Derecho / Education and Law Review, 1, 1-22.

Nussbaum, M. (2010). Not for profit. Princeton, NJ: Princeton University Press.

Plessner, H. (1924). Grenzen der Gemeinschaft: Eine Kritik des Sozialen Radikalismus.

Ragavan, S. K. (2014). Developing ethical values through a mentoring scheme. Legal Ethics, 17(3), 401-424.

Rhode, D. L. (2000). In the interests of justice: Reforming the legal profession. Oxford: Oxford University Press.

Rhode, D. L. (2007). Teaching legal ethics. Saint Louis University Law Journal, 51, 1043-1057.

Rhode, D. L., Luban, D., Cummings, S. L. \& Engstrom, N. F. (2020). Legal ethics. University Casebook Series. St. Paul, MN: Foundation Press.

Vargas, M. \& Doris, J. M. (2021 (in print)). The Oxford handbook of moral psychology. Oxford: Oxford University Press.

Wasserstrom, R. (1975). Lawyers as professionals: Some moral issues. Human Rights 5.

Wolfram, C. W. (1986). Modern legal ethics. St. Paul, MN: West Publishing Co.

$\mathrm{Wu}, \mathrm{R}$. (2017). An empirical study of Hong Kong law students' ethical values: Does common law education enhance their professionalism? Legal Ethics, 20(2), 242-267. 